\title{
Understanding the results of the 1999 Fiji elections
}

\author{
Robert Norton
}

The outcome of the most remarkable parliamentary elections in Fiji's history signalled the possibility of a new phase in political development: a government responding to popular interests that cut across the ethnic divide - the lost promise of the ill-fated Bavadra government of 1987.

While it would be mistaken to infer that the 1999 elections reflect a great weakening of racial or ethnic identities in national politics, it is clear that significant indigenous Fijian support for the still predominantly Indian Fiji Labour Party (FLP) was regained following the dissolution of their interest in it after the military coups 12 years ago. Labour received some of its Fijian support in direct votes, but most through the second and third preferences of its Fijian allies in both communal and open electorates: the Fijian Association Party (FAP), the Party of National Unity (PANU), and the Christian Democratic Party (VLV). Together, these three Fijian parties have followers throughout Fiji, though differing in their regions of greatest popularity. ${ }^{1}$ They attracted 43 per cent of all first preference votes and 70 per cent of the seats in the Fijian communal contests, against the governing Soqosoqo ni Vakavulewa ni Taukei (SVT) Party's 34 per cent of the votes and 22 per cent of the seats in the communal electorates (Figure 4.1).

Leading government with stronger Fijian support than in 1987, the Labour Party had an opportunity to widen its popular base with programs aimed at improving the conditions of life of ordinary people. Its continued national leadership would depend on the success of this project in countering divisions of ethnic interests and agendas within the coalition. Labour's victory rested precariously on a conjunction of contradictory factors including quite disparate ethnic grievances (Indian and Fijian), growing 'class' discontent cutting across the ethnic divide, and the new system of preferential voting which especially favoured the party's strongest Fijian ally, the FAP. 
Figure 4.1 Fijian communal contests: percentage of first preference votes and percentage of seats won

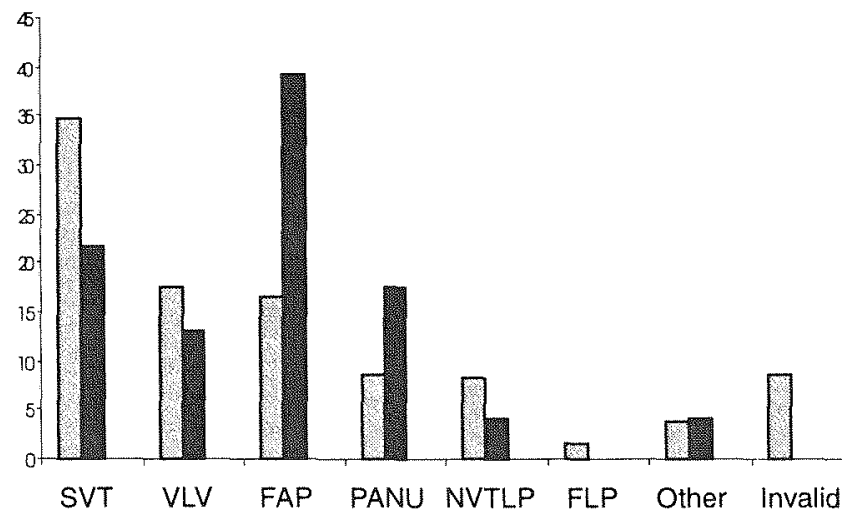

Key: SVT-Soqosoqo ni Vakavulewa ni Taukei; FAP-Fijian Association Party; VLV-Veitokani ni Lewenivanua Vakaristo; PANU-Party of National Unity; NVTLP — Nationalist Vanua Tako/Lavo Party; FLP-Fiji Labour Party.

Source: Fiji Election Office figures, May 1999.

Although interests and meanings of race (or ethnicity) have dominated the shaping of national politics in Fiji, an important question for political development has long been how realities of 'class' (such as economic inequalities) that transcend ethnic difference might be given effective expression in the democratic contest to control the state (Howard 1991; Sutherland 1992). Shared interests as wage workers and consumers are reflected in inter-ethnic cooperation in the powerful trade union movement whose most influential leader, Mahendra Chaudhry, became prime minister. At least 40 per cent of both Fijians and Indians now live and work, or are unemployed, in urban centres, and increasing numbers of people in both groups in the rural areas have interests in common as commercial farmersas reflected, for example, in the cooperation in elections to select farmers' representatives to the Sugar Growers' Council.

However this inter-ethnic convergence in shared material interests has ambiguous political implications. It brings the possibility of intensified ethnic conflict no less than a prospect for unity. This was evidenced after the victory of Bavadra's coalition in 1987 which seemed to promise the political realisation of the class potential. Some of the strongest Taukeist reaction against this coalition's win came from urban Fijians. The Labour Party in that coalition had attracted about 9 per cent of votes in the Fijian communal electorates. But after the coups Fijians began to split from the party, due to the inevitable heightening of ethnic tensions. By the early 1990s most of Labour's leading Fijian stalwarts were rejecting the party for having become an Indian concern. 
So indeed it largely continued to be during the period of the first postcoup Constitution and the phase of constitutional reform from 1994 to 1997. In the first post-coup elections in 1992, Labour contested only four of the 37 Fijian seats, attracting from 3-9 per cent of the votes-a total of 2,654 votes, mostly in western Viti Levu. In the 1994 elections Fijian support dropped to a mere 555 in just two constituencies in western Viti Levu (Norton 1994). At the party's 1995 convention in Nadi, the heartland of western Viti Levu, there was a jarring contrast between its almost entirely Indian male audience and its ethnically and internationally variegated platform of speakers (including political figures from Australia and New Zealand). The event dramatised a tension between the post-coup pressures of ethnic politics, and the leaders' desire to preserve their original image in the hope that the political climate would change. The party continued to have a Fijian president, a former leader of the nurses' union, on whom the Indian principals relied to symbolise the interracial mission and to make aggressive declarations, such as urging Indians to 'agitate and demand' their rights (Fiji Times 3 June 1996:5). ${ }^{2}$

Yet it was in part a shared concern for the plight of the common people (farmers and urban workers) that had brought the Labour leader Mahendra Chaudhry and the coup-maker Sitiveni Rabuka together in 1992 for a shortlived alliance that enabled Rabuka to win office as prime minister against Fijian rivals. It was an astonishing irony, for Chaudhry had been the toughest fibre of the political force Rabuka had sought to demolish at gunpoint. Several months earlier, as his conflict with Prime Minister Ratu Sir Kamisese Mara intensified, the populist Rabuka had championed the cause of aggrieved mineworkers, sugar cane farmers, and nurses. $\mathrm{He}$ publicly drew an invidious contrast between Chaudhry and Mara. Chaudhry, Rabuka declared, was exemplary in his dedicated work for his people, the cane farmers, whereas Ratu Mara ignored the needs of the Fijians.

But Rabuka's flirtation with Chaudhry was encouraged more by fear of a political fragmentation among the Fijians which could undermine his power. This trend became clear in the 1992 and 1994 elections, particularly in the weakening of support for Rabuka's SVT Party in many areas of the main island Viti Levu, where the wage economy and urbanisation are most advanced and where everyday inter-ethnic relations are most common. Interestingly, however, support for the SVT on Viti Levu in 1994 was generally greater in the urban areas themselves (68 per cent on average) than in the rural areas (51 per cent) (Norton 1998). Even in 1999, when the Labour Party regained some urban Fijian support, the SVT's weakest areas were generally not the cities and towns. In fact the party attracted on average 35 per cent of urban Fijian votes, slightly greater than its overall support in the Fijian communal contests and far more than the urban support given 
to any other Fijian party (Table 4.1). The SVT remained the single most popular Fijian political party when first preference votes are considered (Figure 4.1).

The trend to Fijian political fragmentation had continued after the constitutional reform, encouraged by widespread Fijian dissatisfaction with Rabuka for having betrayed the political promise of the coups, as well as having failed to meet their expectations for improved living standards and opportunities. The trend finally overwhelmed his SVT Party in 1999. By contrast, division among Indian voters was far less than it had been since pre-coup elections. It was the unprecedented level of division among Fijians and a new trend to Indian unity behind the party that gave victory to Labour (Table 4.2 and Figure 4.2).

\section{The electoral system}

There were three innovations to the electoral system in the new Constitution: voting was made compulsory for citizens aged 21 years and over, 25 open electorates were superimposed on 45 communal electorates,

\begin{tabular}{lcccccccc}
\hline Table 4.1 & \multicolumn{7}{c}{$\begin{array}{l}\text { Support for parties in Fijian urban communal contests: first preference } \\
\text { votes (per cent) }\end{array}$} \\
& SVT & FAP & VLV & PANU & NVTLP & FLP & Other Invalid \\
Tamavua/Laucala & 40 & 27 & 26 & - & - & - & - & 7 \\
Southwest Urban & 39 & 21 & 18 & - & 6 & 8 & 1 & 7 \\
Suva City & 37 & 14 & 22 & - & 8 & 12 & - & 7 \\
Nasinu & 31 & 24 & 22 & - & 10 & - & 5 & 8 \\
Northwest Urban & 30 & - & 19 & 41 & 5 & - & - & 5 \\
Northeast Urban & 35 & 25 & 19 & - & 15 & - & - & 6
\end{tabular}

Note: SVT_Soqosoqo ni Vakavulewa ni Taukei; FAP_Fijian Association Party; VLV-Veitokani ni Lewenivanua Vakaristo; PANU-Party of National Unity; NVTLP-Nationalist Vanua Tako/Lavo Party; FLP - Fiji Labour Party.

Source: Fiji Election Office figures, May 1999.

Table 4.2 Indian communal voting, 1992-99

\begin{tabular}{lcccccc} 
& \multicolumn{2}{c}{1992} & \multicolumn{2}{c}{1994} & \multicolumn{2}{c}{1999} \\
& Seats & Votes (\%) & Seats & Votes (\%) & Seats & Votes (\%) \\
FLP & 13 & 47 & 8 & 42 & 19 & 60 \\
NFP & 14 & 50 & 19 & 54 & - & 29 \\
Other & - & 3 & - & 4 & - & 2 \\
Invalid &.. &.. &. &.. & - & 9
\end{tabular}

Key: FLP-Fijian Labour Party; NFP-National Federation Party. 1992 and 1994 invalids not included.

Source: Fiji Election Office figures, May 1999. 
and a preferential voting system (the 'Alternative Vote') replaced the old 'first-past-the-post' system. Voters' second and third preferences were distributed when no candidate gained more than 50 per cent of the first preference votes. The composition of the open electorates was multiethnic and their seats were not ethnically reserved. The ethnic composition of these electorates is shown in Figure 4.3.

From 1966 until 1987 there had been some 'cross-voting' electorates in addition to a majority of communal ones (Lal 1992; Lawson 1991; Norton 1990). They were introduced as a compromise with the longstanding call by most Indian leaders for fully common roll elections. Although they were multiethnic in composition, their seats were ethnically reserved. Most of these electorates each had an Indian and a Fijian seat, and every elector voted in both a communal and an encompassing cross-voting electorate. Like the communal contests, cross-voting contests could only be between candidates of the same ethnic group, so that elections could never alter the ethnic balance in parliament. Thus while it was true that Bavadra's government was elected very largely by Indian voters, there were no more

Figure 4.2 Indian communal voting: percentages of first preference support for the FLP and the NFP in the 19 electorates

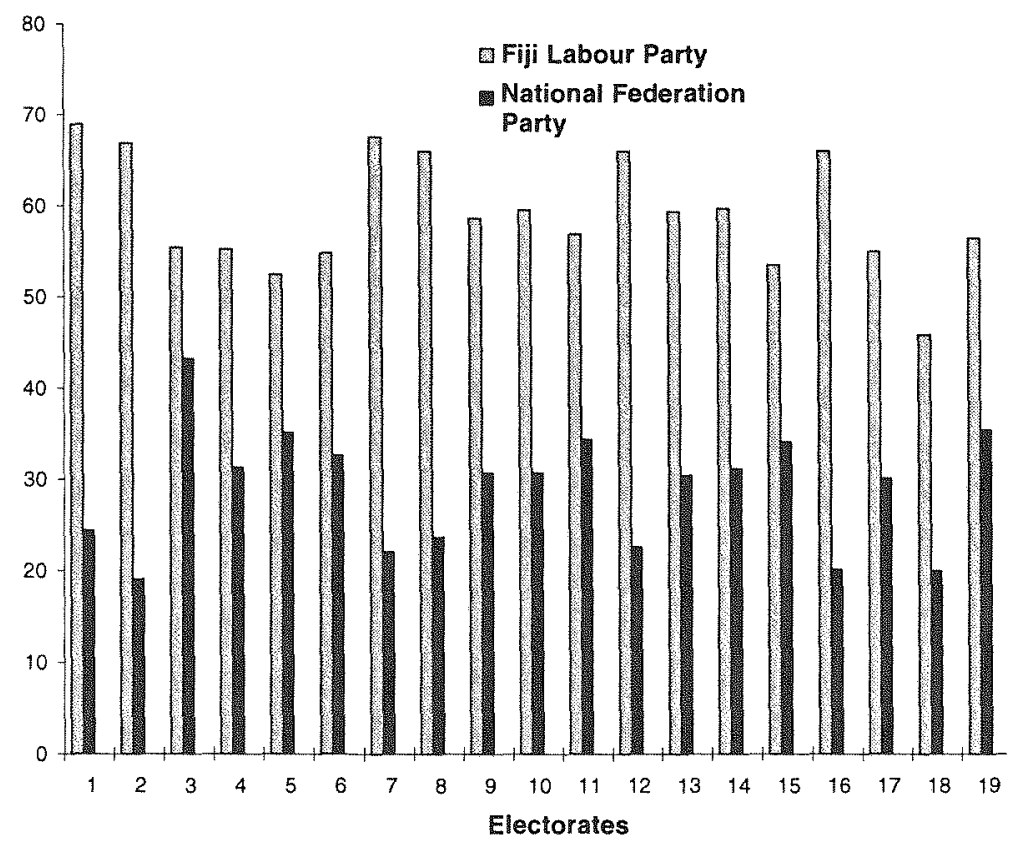

Key: 1. Nasinu, 2. Laucala, 3. Suva City, 4. Viti Levu South-Kadavu, 5. Tailevu-Rewa, 6. Viti Levu East-Maritime, 7. Tavua, 8. Ba East, 9. Ba West, 10. Lautoka Rural, 11. Lautoka City, 12. Vuda, 13. Nadi Rural, 14. Nadi Urban, 15. Nadroga, 16. Labasa, 17. Macuata East-Cakaudrove, 18. Labasa Rural, 19. Vanua Levu West.

Source: Fiji Election Office figures, May 1999. 
Figure 4.3 Ethnic composition of the open electorates

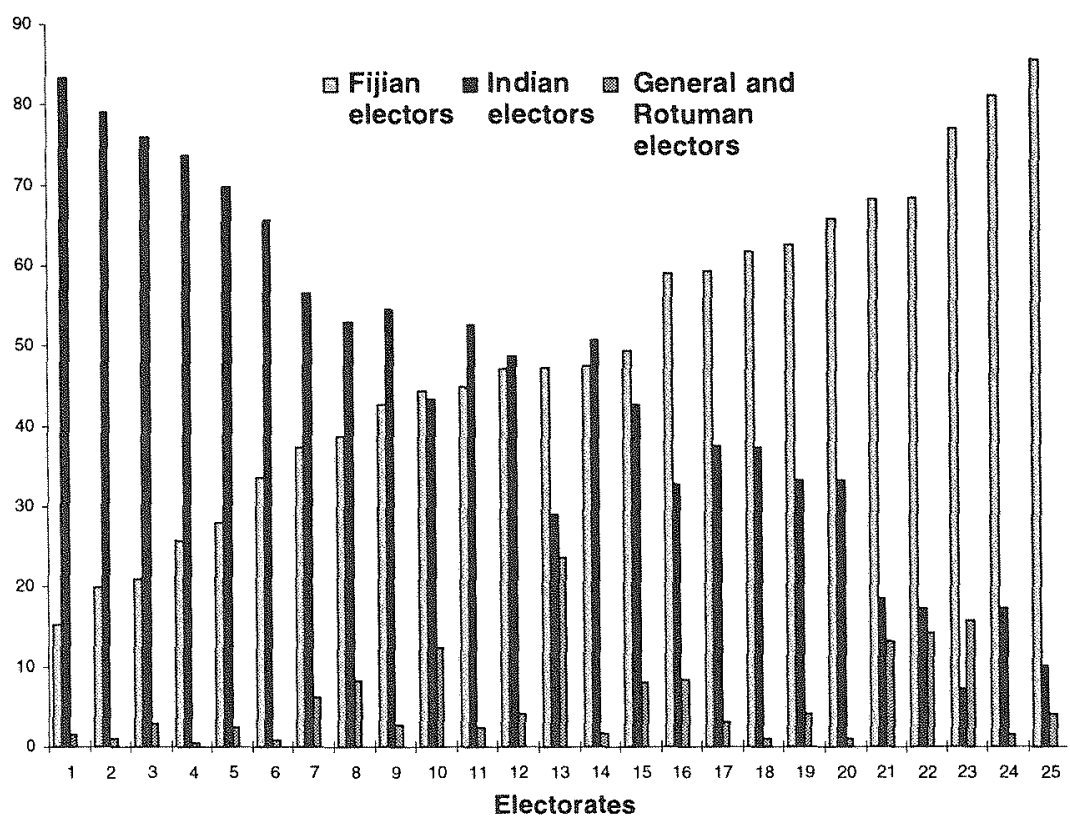

Key: 1. Ba, 2. Macuata East, 3. Labasa, 4. Magodro, 5. Vuda, 6. Yasawa-Nawaka, 7. Nadi, 8. Lautoka City, 9. Tavua, 10. Samabula-Tamavua, 11. Nasinu-Rewa, 12. Nausori-Naitasiri, 13. Suva City, 14. Nadroga, 15. Laucala, 16. Cunningham, 17. Bua-Macuata, 18. Ra, 19. Serua-Navosa, 20. Tailevu South-Lomaiviti, 21. Lami, 22. Cakaudrove West, 23. Lau-Taveuni-Rotuma, 24. Lomaivuna-NamosiKadavu, 25. Tailevu North-Ovalau.

Source: Fiji Election Office figures, May 1999.

Indians in the parliament than before. What had shifted, to some extent, were the party alignments of Fijian and Indian candidates, and of Fijian and Indian voters. Moreover, the cross-voting electorates did make it easier for a party such as Labour to appeal directly for Fijian votes.

The 1990 Constitution under which the 1992 and 1994 elections were conducted abolished cross-voting. There were only communal electorates, with 37 seats for Fijians, 27 seats for Indians, 5 for Generals, and one Rotuman. Rabuka's SVT Party, authorised by the Council of Chiefs, dominated the House of Representatives with a majority of the Fijian seats. The Council of Chiefs' nominees dominated the upper house (Senate). Indian leaders declined invitations to join the cabinet under this Constitution.

The Constitution Review Commission of 1995-6, headed by Sir Paul Reeves, recommended a new electoral system to comprise 45 open or 'common roll' electorates with no ethnic reservation of seats, and only 25 communal electorates each with an ethnically reserved seat. The objective was 'to encourage the emergence of a multiethnic political culture' (Reeves 
et al. 1996:309). However, the ratio was reversed by the Joint Parliamentary Select Committee which, under Rabuka's leadership, reviewed the Reeves report and decided the terms of the new Constitution. The two main Indian groups, the National Federation Party (NFP) and the Fiji Labour Party (FLP), were divided on this issue of the electoral system. The FLP urged accepting the Reeves Commission's proposal, while the NFP agreed with the Fijian and General leaders that communal representation should continue to predominate.

The communal seats included 23 Fijian, 19 Indian, and 3 General. There was also one Rotuman electorate and seat. Most of the Fijian electorate boundaries corresponded with those of the old provinces, but the three most populous provinces ( $\mathrm{Ba}$, Cakaudrove and Tailevu) were each split into two electorates. The 23 Fijian electorates averaged around 9,000 electors, but ranged very widely in size from Namosi 2,856 to Nadroga/Navosa 16,047 , each with just one seat. The 19 Indian electorates averaged about 10,000 , ranging from 7,760 in Viti Levu East/Maritime to 14,454 in Laucala (in Suva). The 3 General electorates ranged from Suva City 3,772 to Western/ Central 5,701. The 25 open electorates ranged in size from Suva City 15,566 to Nadi 21,020 . They varied widely in their ethnic composition, but with an overall balance of some predominantly Fijian and some predominantly Indian electorates and a range of ethnic proportions between these extremes (Figure 4.3). As in the pre-coup system, voters were entitled to two votes: one in their communal electorate, and one in the open electorate of which their communal electorate, or a section of it, was part.

The introduction of open electorates, for the first time outside of town government, enabled direct contests between candidates of different ethnicity for the same seats, and hence allowed the election process to determine the ethnic proportions in the House of Representatives. More importantly, the change favoured the development of multiethnic political parties, though this potential has yet to be strongly realised.

An upper house, the Senate, was preserved, though altered in composition. It had 32 members appointed by Fiji's president, who was selected by the Council of Chiefs. Fourteen were nominated by the Council of Chiefs, 9 chosen by the Prime Minister, 8 by the Leader of the Opposition, and 1 by the Council of Rotuma. The chiefs were more strongly represented than they were under the pre-coup Constitution, but well below their strength under the 1990 Constitution.

\section{The 1999 elections}

The constitutional reform reconstructed, perhaps more surely than ever before, an institutional and ideological framework for containing Fijian ethno-nationalism and encouraging inter-ethnic political cooperation, both in election campaigning and in the formation and conduct of government. 


\begin{tabular}{lrrlrrr}
\hline Table 4.3 & Fiji's population and registered voters by ethnicity & \\
Population & No. & \multicolumn{1}{c}{$\%$} & Registered electors & No. & $\%$ \\
Indigenous Fijians & 393,575 & 50.8 & Fijians & 210,209 & 50.6 \\
Indians & 338,818 & 43.7 & Indian & 187,154 & 45.1 \\
Part-Europeans & 11,685 & 1.5 & General & 12,679 & 3.1 \\
Rotumans & 9,727 & 1.3 & Rotuman & 4,896 & 1.2 \\
Other Pacific islanders & 10,463 & 1.4 & Total & 414,938 & \\
Chinese & 4,969 & 0.6 & & & \\
European & 3,103 & 0.4 & & & \\
Others & 2,767 & 0.4 & & & & \\
Total & 775,077 & & & & &
\end{tabular}

Note: General electors include mainly Part-Europeans, Pacific Islanders other than Fijians and Rotumans, Chinese, and Europeans. Tiny Rotuma is Fiji's Polynesian dependency, but a majority of the Rotumans reside on Fiji's main island, Viti Levu.

Source: Fiji Election Office figures.

The Constitution required that the prime minister must invite into his cabinet in proportion to their strength all parties whose membership in the House of Representatives comprised at least 10 per cent of the total membership of the House-in practice, 8 of the 71 seats.

In their joint campaigning, Rabuka and Reddy as leaders of the SVT and the NFP respectively, promised to strengthen 'multiracialism', political stability, and economic prosperity on the basis of their crucial collaborative roles in the achievement of the constitutional reform. NFP rhetoric sometimes warned of the danger of ethnic violence, pointing to recent tragedies in other parts of the world. The persistence of ethnically divisive issues concerning land and political power gave relevance to this platform. However, the new Constitution had opened the way for a new direction in political leadership on 'bread and butter' concerns of everyday popular life that transcended the ethnic differences.

The strategic alliance which devastated the SVT-NFP-UGP coalition was led by the FLP which, with its uncompromising universalist ideology, had been marginalised during the process of constitutional reform as Reddy, the NFP leader, dealt more effectively with Rabuka and the SVT (Lal 1998; Norton 2000). Ironically, however, Labour owed its victory not just to the new popularity of its ideology (mainly with Indian voters), but much more to the unprecedented political fragmentation of Fijians that had been provoked partly by resentment against Rabuka's compromising with Indian demands.

Some Fijian leaders denounced Rabuka for betraying the promise of his coups by agreeing to a change that would jeopardise indigenous power. They pointed out that a majority of the Fijian provincial councils had originally opposed the Reeves Commission's proposals for reform. While 
this issue was helping several Fijian parties to erode the SVT's popular base, Reddy's NFP was losing every seat to Labour. The catastrophic NFP defeat was due partly to the unpopularity of the party's alliance with the coup-maker and to anxieties about the future of farm leases. On the latter issue, the NFP often seemed more deferential to the Fijian owners than concerned to defend the Indian tenants, as many leases began to run out and, in some localities, landowner harrassment intensified.

Both the SVT and the NFP were weakened also by discontents over unemployment and poverty, and allegations of government neglect, mismanagement and corruption. Labour and its main Fijian allies (FAP and PANU) appealed to these concerns under the banner of 'The Peoples' Coalition'. Rabuka's strongest Fijian rivals had joined forces with the Labour Party in varying degrees and from differing motives, and Labour itself campaigned with a renewed Fijian participation, both in its leadership and among its candidates.

The splitting of the Fijians among several Fijian parties and the FLP (Labour), decimated the governing SVT Party both in the Fijian communal electorates and in the open electorates. In the communal contests, the SVT was reduced from the 65 per cent of votes won in 1994, to just 34 per cent. It was an unprecedented fall in popularity for a dominant Fijian political party (Figure 4.4). The party won only 8 seats ( 5 communal and 3 open)11 per cent of the parliament. Labour won 37 seats (19 Indian communal and 18 open) -52 per cent of parliament (Figure 4.5). With its Fijian allies and the support of the sole Rotuman member, Labour held 56 seats (nearly 80 per cent). By ethnicity they were 30 Indians, 25 Fijians, and one Rotuman (Table 4.4).

Labour defeated the NFP in all communal Indian and in all open contests (Figure 4.2 and Table 4.2). Labour did not contest any of the three General seats, two of which went to independent candidates and one to the UGP in coalition with the SVT and NFP.

\section{The effect of preferential voting}

Preferences were distributed where no candidate achieved over 50 per cent of the votes on the first count. This was so in 18 of the 25 open contests, 16 of the 23 Fijian communal contests, 2 of the 3 General communal contests, but in none of the 19 Indian communal contests. The need to distribute second and third preferences was of course linked to the number of candidates competing for a seat-an average of 5.3 for the open seats, 4.3 for the Fijian communal, 4 for the General communal, but only 2.6 for the Indian communal seats.

In some cases 'dummy' candidates had been fielded to maximise the impact of preferences. For example, in several open electorates the SVT encouraged Fijians to vote for the NFP but also fielded its own candidate 
to help split the voting and to direct the preferences of supporters who would not tick the NFP. In several other contests the NFP used the same strategy when it favoured the SVT candidate (Table 4.5).

It is interesting to compare the election outcome with what would have been the result if the contests were all decided, as previously, by the largest first preference vote; that is, 'first past the post' (Table 4.6). Labour would still be the strongest group in parliament, with 33 of the 71 seats, though only 4 of its members would be Fijians, instead of 7. Only 4 of Labour's 18 open seats depended on preferences, and not one of its 19 communal Indian

Figure 4.4 Support for major Fijian political parties, 1966-99 (per cent)

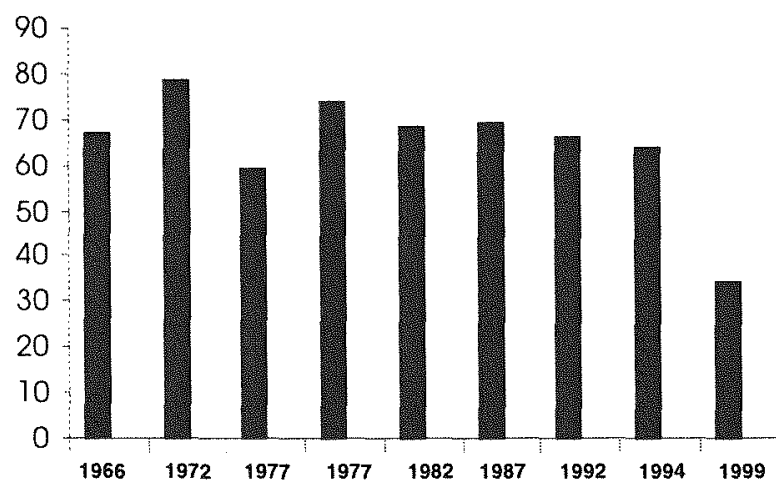

Key: 1966-87 Fijian Association (main body in the Alliance Party); 1992-99 Soqosoqo ni Vakavulewa ni Taukei (SVT).

Source: Norton, R., 1990. Race and Politics in Fiji, University of Queensland Press, St. Lucia (rev. ed); Norton, R., 1998. 'Politics in Fiji', in R. Chandra (ed.), Atlas of Fiji, School of Social and Economic Development, University of the South Pacific, Suva.

Figure 4.5 Support for parties in the open contests-first preference votes and seats won

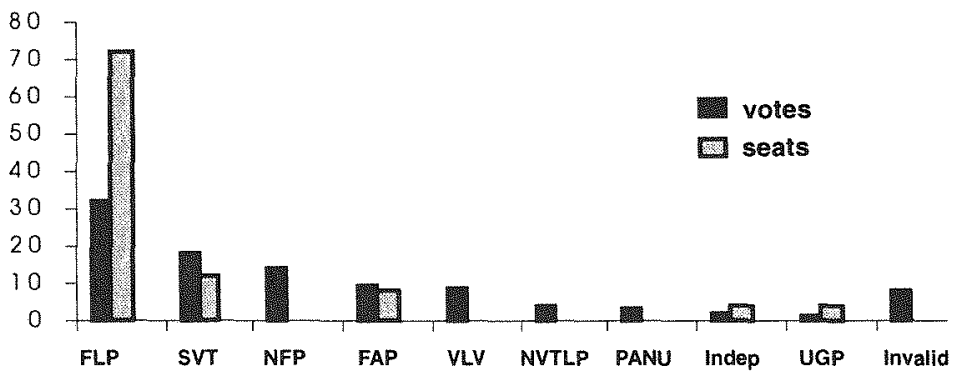

Source: Fiji Election Office figures, May 1999. 
seats did-the party won every Indian seat by voters' first choice, which averaged twice the vote for the NFP (Figure 4.2).

But the fortunes of the SVT and its main Fijian rival (the FAP) would have been dramatically reversed. The SVT would have 18 seats instead of a mere 8 (11 communal and 7 open), and the FAP, Labour's major ally, would have only 6 seats instead of 11 ( 4 communal, 2 open). While Labour's other main Fijian ally, PANU, would still have its 4 seats, the VLV, informally a Labour ally, would have secured just 2 seats not 3 . The SVT partner, the UGP, would have 4 seats rather than 2 . Figure 4.6 shows the size of discrepancies between first preference and final votes for winning candidates in the open and the Fijian communal contests.

Clearly it was in the Fijian communal contests where the preferential voting system had the greatest effect. The SVT was isolated by the combined hostility of its Fijian rivals. Most directed preferences well away from the SVT leaving it at or near the bottom of their lists, and in the open electorates they shared preferences with Labour which often also ranked even the most conservative Fijian groups ahead of the SVT. The parties encouraged voters to endorse the parties' preferences by ticking the party box above the line on the ballot paper, rather than making their own rankings in a list below the line. Confusion over the new system often resulted in invalid votes (in some electorates as high as 14 per cent), and many Fijian voters later complained that they had not understood that endorsing their party's preferences could help the predominantly Indian Labour Party to victory.

But far more important for the Labour victory than the allocation of preferences was simply the political fragmentation of the Fijians. While in the Fijian communal electorates Labour gained indirectly from the victories of its allies who took 16 of these 23 seats, in the open electorates it owed 7 of its own 18 wins to the Fijian splitting (Laucala, Lami, Cunningham,

\begin{tabular}{lccccc}
\hline Table & \multicolumn{5}{l}{ Ethnic composition of House of Representatives, after 1999 elections } \\
Party & Fijian & Indian & General & Rotuman & Total \\
FLP & 7 & 30 & - & - & 37 \\
SVT & 8 & - & - & - & 8 \\
FAP & 12 & - & - & - & 12 \\
PANU & 4 & - & - & - & 4 \\
VLV & 3 & - & - & - & 3 \\
UGP & - & - & 2 & - & 2 \\
Other & 1 & 1 & 2 & 1 & 5 \\
Total & 35 & 31 & 4 & 1 & 71 \\
Note: FLP-Fiji Labour Party; SVT-Soqosoqo ni Vakavulewa ni Taukei; FAP-Fijian Association \\
Party; PANU-Party of National Unity; VLV-Veitokani ni Lewenivanua Vakaristo; UGP-United \\
General Party. \\
Source: Fiji Election Office, election results.
\end{tabular}




\begin{tabular}{lrr}
\hline Table 4.5 & \multicolumn{2}{c}{ 'Dummy' candidates fielded by the NFP and SVT in 20 open electorates } \\
Electorate & NFP & SVT \\
Nadroga & $35^{\star}$ & 6,377 \\
Tailevu South Lomaiviti & $22^{*}$ & 6,161 \\
Bua Macuata & $18^{*}$ & 5,897 \\
Suva City & $89^{*}$ & 1,040 \\
Magodro & 3,927 & 1,169 \\
Cunningham & $41^{*}$ & 4,833 \\
Lami & - & - \\
Ra & - & 3,495 \\
Tavua & 1,476 & 2,603 \\
Macuata East & 4,038 & - \\
Ba & 5,285 & $46^{*}$ \\
Vuda & 4,096 & 2,410 \\
Laucala & $68^{*}$ & 4,125 \\
Nadi & 5,653 & $156^{\star}$ \\
Labasa & 4,246 & - \\
Yasawa Nawaka & 4,651 & $24^{*}$ \\
Nasini Rewa & 3,920 & $131^{*}$ \\
Nausori Naitasiri & 4,044 & $169^{\star}$ \\
Lautoka City & 5,255 & $192^{*}$ \\
Samabula Tamavua & 4,726 & $565^{\star}$
\end{tabular}

Note: *Number of votes received for 'Dummy' candidates.

Source: Fiji Election Office figures, May 1999.

\begin{tabular}{|c|c|c|c|c|}
\hline \multirow[t]{3}{*}{ Table 4.6} & \multicolumn{4}{|c|}{$\begin{array}{l}\text { Effects of preferential voting: actual results compared with hypothetical } \\
\text { 'first-past-the-post' outcome }\end{array}$} \\
\hline & \multicolumn{2}{|c|}{$\begin{array}{l}\text { Actual number of } \\
\text { seats won }\end{array}$} & \multicolumn{2}{|c|}{$\begin{array}{l}\text { Hypothetical seats won } \\
\text { by voters' first choice }\end{array}$} \\
\hline & Communal & Open & Communal & Open \\
\hline FLP & 19 & 18 & 19 & 14 \\
\hline SVT & 5 & 3 & 11 & 7 \\
\hline FAP & 9 & 2 & 4 & 2 \\
\hline VLV & 3 & - & 2 & - \\
\hline PANU & 4 & - & 4 & - \\
\hline NVTLP & 1 & - & 1 & - \\
\hline UGP & 1 & 1 & 3 & 1 \\
\hline Other & 4 & 1 & 2 & 1 \\
\hline
\end{tabular}


Figure 4.6(a) Effects of preferential voting-percentages of first preference vote and final vote for winning candidates: open electorates

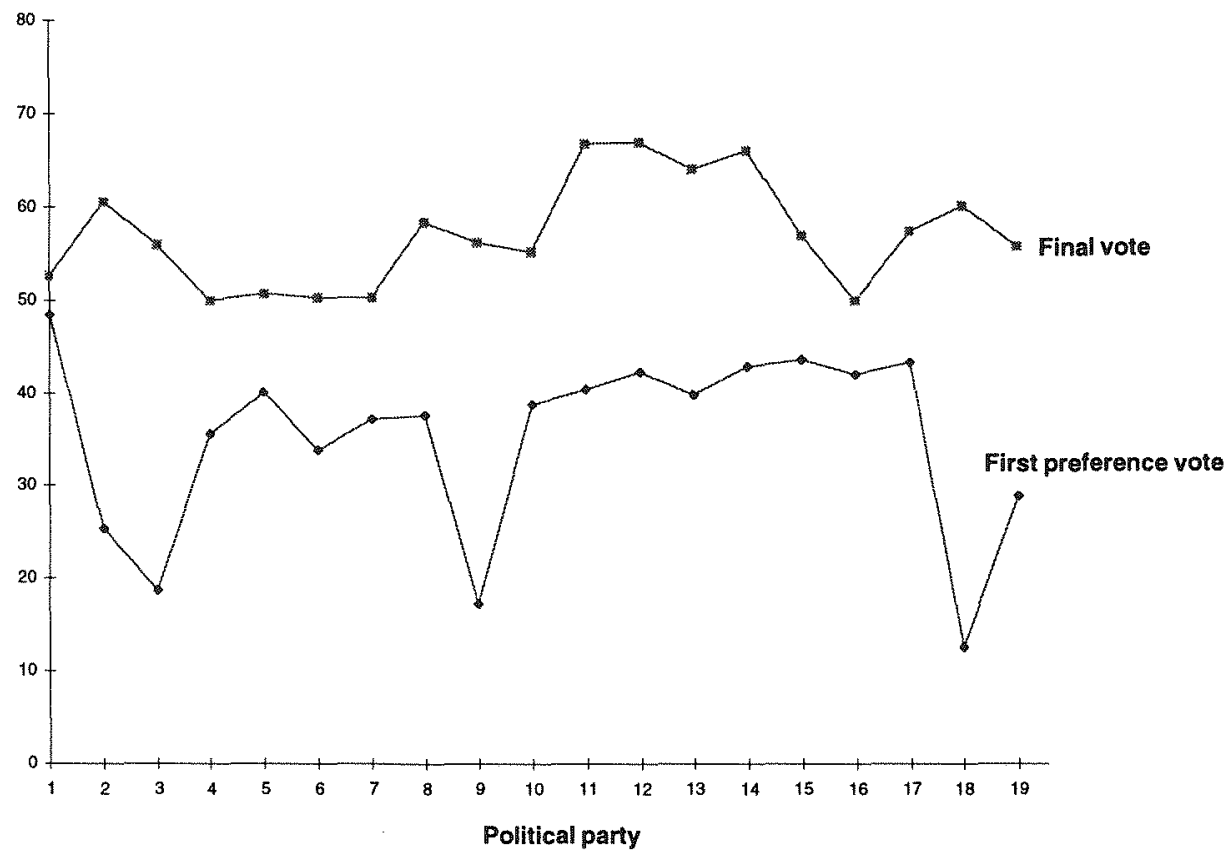

Key: $\mathrm{FLP}=1-14 ; \mathrm{FAP}=15,16 ; \mathrm{SVT}=17 ;$ Independent $=18 ; \mathrm{UGP}=19$

Source: Fiji Election Office figures, May 1999.

Figure 4.6(b) Effects of preferential voting-percentages of first preference vote and final vote for winning candidates: Fijian communal electorates

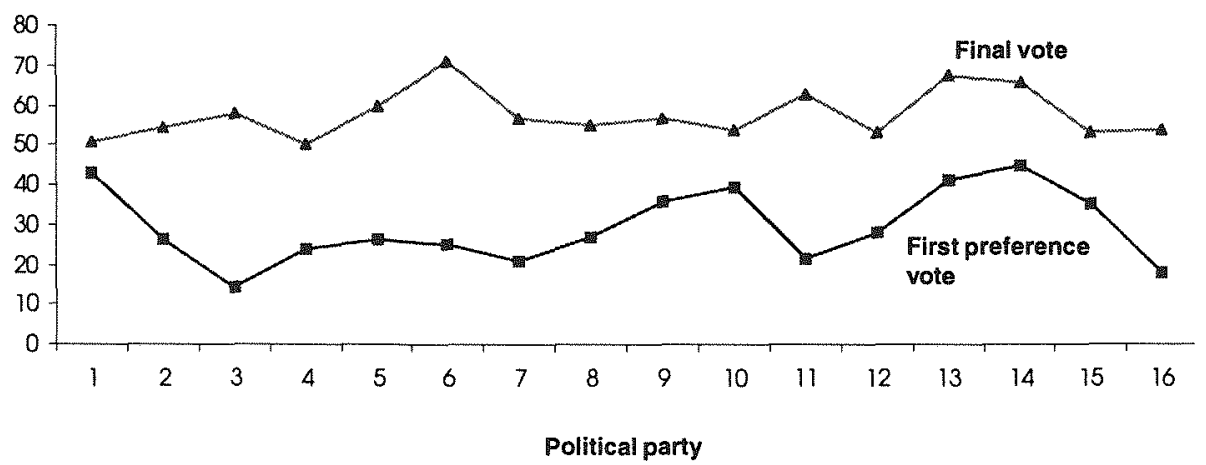

Key: FAP $=1,3-9 ;$ Independent $=2 ; \mathrm{VLV}=10 ; \mathrm{NVTLP}=11 ; \mathrm{PANU}=12-14 ; \mathrm{SVT}=15-16$. Source: Fiji Election Office figures, May 1999. 
Nadroga, Tailevu South/Lomaiviti, Bua/Macuata, Nadi). Fijian rivalries allowed the Labour candidates to emerge as the strongest contenders for these seats even on the first count.

The Fijian political fragmentation was encouraged partly by division among leaders of high chiefly rank. In its campaign rhetoric the SVT continued to emphasise that it had been formed under the authority of the Great Council of Chiefs. But several prominent chiefs, including the retired army commander and a daughter of Fiji's President, were now aligned with rival parties. One of the foremost chiefs, Adi Lala Mara, wife of Fiji's President, publicly repudiated the SVT claim to still have Council of Chiefs endorsement. An objective of the VLV, her daughter's party, was to restore a central role for the chiefs in national leadership which, it alleged, had been degraded by the Rabuka government. ${ }^{3}$ PANU and the FAP, the other main challengers to the SVT, also enjoyed the leadership or support of important chiefs.

\section{Labour's paradoxical gain from Fijlan ethnic conservatism}

The starkest irony of the elections was the massive popular rejection of the leaders who, over four years, had played the major roles in the dialogue and negotiation that enabled the reform of the racially-biased post-coup Constitution. They confidently relied on their momentous achievement to no avail in their election campaigning.

For both the SVT and the NFP, the constitutional reform was a doubleedged sword. Its success had produced their coalition. But Indian voters at the very least either were not identifying the reform with the coalition, or they saw no continuing relevance of the coalition for their interests. Certainly their opposition to Reddy's electoral alliance with the coup-maker seemed to outweigh their perception of any likely benefits from the partnership - for all Reddy's reminders of tragic ethnic conflicts in other parts of the world and his urgings about the wisdom of working with the 'mainstream' Fijian political party to ensure harmony and achieve further reforms, particularly in respect to land leases. One of Labour's principal Fijian candidates, Tupeni Baba, before his Indian audiences, derided Reddy for trying to lead them to Rabuka's SVT just as Fijians were deserting it in droves! (Suva Civic Centre 5 May 1999). Rabuka's belated 'apology' for the hurt of his coups was occasioned, toward the end of the campaigning, by mounting criticism of the NFP for betraying the Indian people in uniting with the ruling party. The dramatic highpoint of Labour's last mass rally in Suva, was an indignant Mahendra Chaudhry playing a tape recording of Reddy's declaration during the 1994 elections that he would 'never endorse Rabuka for prime minister because of the suffering caused by his coups'. But Indians rejected the NFP also for joining with the party seen to 
be responsible in government for economic recession and corruption, after years of opposing it for these failings.

Many Fijians viewed the constitutional reform as a betrayal of the promise of the coups because its emphasis was on inter-ethnic power sharing. Certainly, for most Fijians, the constitutional reform was not a reason to vote for the SVT, and many were attracted by the promises of other Fijian parties to strengthen Fijian control over their lands at a time when Indian tenant farmers were becoming anxious about the future of their farms. A common question Fijians put to SVT candidates in villages and towns mirrored that being put by Indians to NFP campaigners: 'Why has the SVT joined with an Indian party?' Some candidates replied by stressing the importance of the new Constitution, the need 'to come together', and the correctness of this according to Christian values.

All the SVT's rivals, to varying degrees and in different places, encouraged Fijian discontent with Rabuka's compromising on the Constitution, as well as with his government's alleged economic mismanagement and corruption. This was especially true of the VLV and the Nationalist Vanua Tako Lavo Party (NVTLP). But each of Labour's Fijian party allies was characterised by a spectrum of outlooks and agendas, from ethno-nationalist to liberal. The VLV fanned ethnic sentiments with rhetoric about making Fiji a Christian state and bringing back the Sunday Observance Decree-though this call was eventually moderated for the sake of an informal alliance with Labour.

Ironically, the ethnocentrism encouraged by Fijian anti-SVT forces helped the ideologically universalist Labour Party by strengthening the popularity of its Fijian allies, and simply by splitting Fijian votes in the open contests. The party most strongly identified ideologically with constitutional reform, but which had been sidelined in the reform process, finally gained from Fijian opposition to reform.

\section{Voting across the ethnic divide}

Labour's pragmatic alliances in contravention of its ideological commitments do not account for its small but significant direct Fijian support, encouraged by some of the same discontents that compelled much of the party's Indian following. For urban audiences particularly, there was a striking contrast between the immediate relevance of the Labour Party's detailed criticisms and promises, and the SVT/NFP Coalition's platitudinous rhetoric about 'multiracialism', political stability, and economic growth. It was not that such goals were seen as unimportant, but simply that their proclamation could have little appeal against the powerful resonance of Labour's sharply focussed analysis of Fiji's problems, with widespread popular anxieties and frustrations: 'If the SVT/NFP Coalition 
wins government', Chaudhry warned his last Suva rally, 'they will inflict more pain and suffering on you!' (Suva Civic Centre 5 May 1999).

The SVT/NFP Coalition's faith in the power of their constitutional reform to carry the day for them seemed strangely out of touch with social realities. The period of the reform, from 1994 to 1997, had been a phase of redemption, of reconciliation and political reconstruction, after the trauma of the coups and an ethnically hegemonic Constitution (Lal 1998; Norton 2000). The tensions and uncertainties of this phase had kept ethnic concerns to the forefront and strengthened the identities of Reddy and Rabuka as national leaders. But the very success of the reform helped to free the political arena for new issues. There had been an accumulation of many sources of popular discontent, and it seemed that the achievement of a new Constitution opened the gate for an outpouring of the pent-up grievances.

Labour and PANU were the only parties with an ideological commitment to being multiethnic. But PANU, a Fijian group based in Western Viti Levu, fielded only one Indian communal candidate who attracted a mere 153 votes, and two Indian candidates for open seats (3,827 votes). The FAP supported three Indian and two General candidates for communal contests (the Indians winning 955 votes, the Generals 1,052). Even the VLV had an Indian candidate for an open contest in western Viti Levu (490 votes). But such inter-ethnic collaboration was intended mainly to assist in the splitting of votes.

The FLP (Labour) was clearly the only party that was substantially multiethnic in its leadership and popular following. A final rally packing the Suva Civic Centre auditorium three days before polling began included many enthusiastic Fijians. It was common to hear Fijians talking favourably about the party, and in some parts of Suva they held fund collecting drives (soli) for it. Labour contested four of the 23 Fijian communal seats, two of them in urban areas including Suva City, gaining from 7-12 per cent of the votes $(3,352)$-though only 1.7 per cent of all Fijian communal votes (Figure 4.1). The party left several other Fijian contests to its allies, the FAP and PANU. All seven of Labour's Fijian candidates for open seats were elected, five of them in electorates where Fijian voters equalled or outnumbered Indian voters (Tailevu South/Lomaiviti, Cunningham, Samabula/ Tamavua, Nadroga, Bua/Macuata West). In many other contests, both for communal and open seats, Labour encouraged support for its Fijian allies.

The communal figures do not reveal the magnitude of the direct indigenous Fijian support for Labour because the mere 1.7 per cent reflects the party's decision to leave most Fijian contests to its Coalition partners. However, the open results might reflect a considerably stronger Fijian interest in Labour. The FLP attracted 108,743 votes in the Indian communal contests, but 119,571 in the open contests. This increase of 10 per cent may comprise many Fijian and General votes. 
A clearer indication of the possible scale of Fijian support for Labour might be found by comparing the ethnic composition of open electorates with the actual voting pattern, to gain a rough measure of the extent to which support for parties exceeded what might be expected if people voted simply on ethnic lines (Table 4.7 and Figure 4.7). Figure 4.7 makes two comparisons: (a) the total first preference votes received for the FLP, the NFP, and other Indian candidates in each of the 25 open constituencies, is compared with a hypothetical quantity of votes projected from the number of registered Indian electors in each constituency - the hypothetical vote is the portion of all actual valid votes in the electorate which we might expect to have been cast by the Indian electors; and (b) the total number of first preferences for Fijian candidates (other than FLP candidates) in the 25 constituencies, is compared with hypothetical quantities of Fijian votes calculated on the basis of the numbers of registered Fijian electors. The horizontal line represents equivalence of the figures in each comparison. The columns above and below this line show the extent to which actual voting exceeds or falls short of that hypothetical equivalence-that is, they represent the likely degrees of cross-ethnic voting. ${ }^{4}$

This is not an entirely reliable way of assessing the extent of cross-ethnic voting because we do not know the ethnic proportions of the actual voters, nor the ethnic makeup of invalid votes. I have assumed that these proportions are comparable to the ethnic composition of the registered electors. Average invalid voting in the communal electorates was about 9 per cent for Fijians and 10 per cent for Indians, suggesting that there may have been little ethnic difference in the invalid voting in the open electorates. Although the overall ethnic difference in the proportions of registered electors who voted was slight $(92$ per cent for Indians and 89 per cent for Fijians), the differences for particular open electorates are not known. My calculations also do not take account of the General electors and Rotuman electors whose combined strength among registered voters varied from 0.3-14.2 per cent, and averaged 4.6 per cent in the open electorates (Table 4.7). However, I do not think this would greatly modify the patterns in the figures.

If people had voted overwhelmingly on communal lines, we would expect to see a close correspondence between the ethnic composition of the registered electors in a particular constituency, and the division of votes between the predominantly ethnic parties. The number of votes for the FLP plus NFP (plus the few other Indian candidates) would be comparable to a figure projected on the basis of the number of registered Indian voters in the electorate, and the votes for Fijian parties and Fijian independents would resemble figures projected from the number of registered Fijian voters.

In fact, the pattern of correspondence and discrepancy between actual and projected figures indicates substantial degrees of voting across the 
ethnic divide, especially non-Indian support for the parties that have been identified as Indian or primarily Indian, the NFP and the FLP (the lightshaded columns above the line on the right side of the figure), and nonFijian support for Fijian parties (dark-shaded columns above the line on the figure's left). There are several open constituencies, mainly urban, where the support gained by the 'Indian' parties must have included a substantial number of Fijian voters (Nos 16-25). Similarly, there are several open constituencies where the support for Fijian parties must have included a substantial number of Indian votes (Nos 1-9, especially 1, 2, 3, and 8).

Figure 4.7 presents the open electorates in order of the extent to which the totals of votes for FLP, NFP, and other Indian candidates fell below or exceeded the hypothetical projected votes by registered Indian electors. Toward the right of the figure, the volume of votes in excess of the projected votes corresponds with shortfalls of votes for Fijian parties and Fijian

\section{Figure 4.7 Cross-ethnic first preference voting in open electorates}

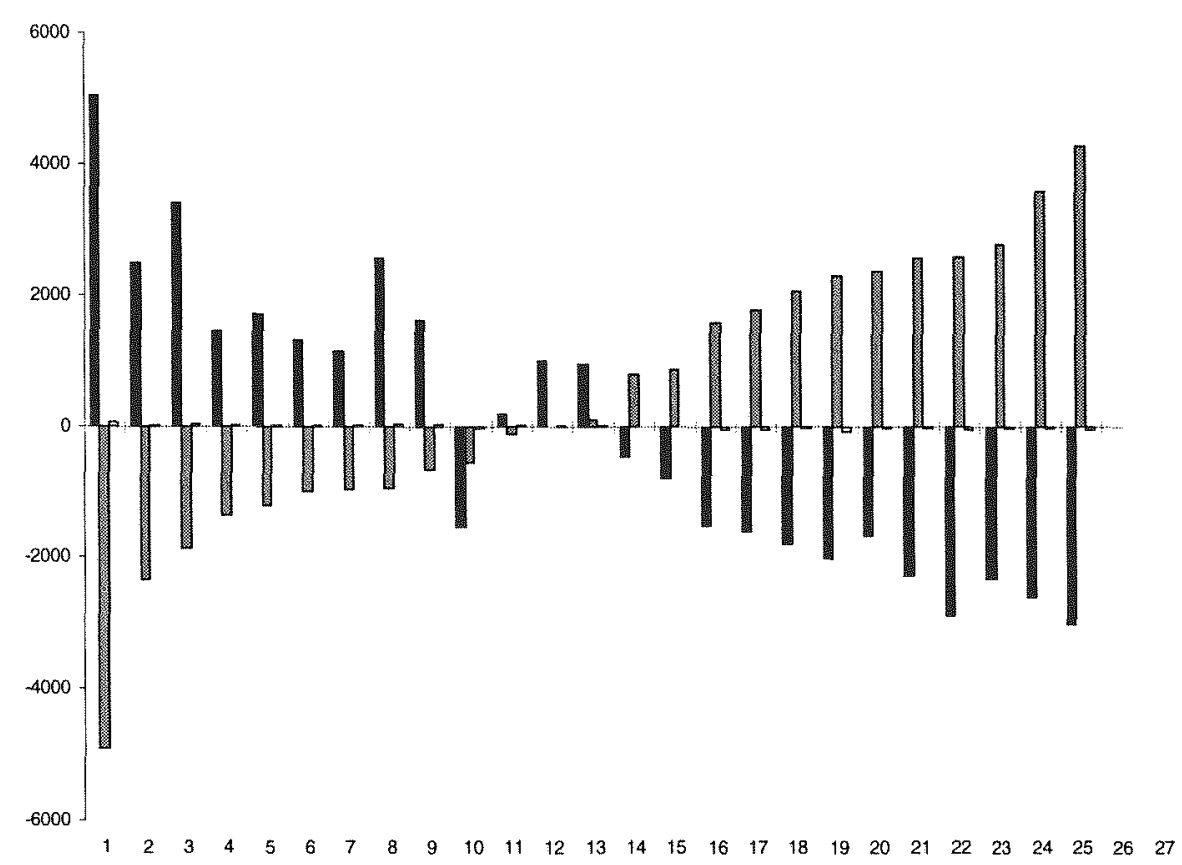

Key: Black: Difference between actual and projected votes for Fijian political parties and other Fijian candidates (other than those for FLP)

Grey: Differences between actual and projected votes for FLP, NFP, and other Indian candidates (calculations include 4,317 votes given to Indian candidates sponsored by the Fijian parties PANU and VLV).

Note: see Table 4.7 for constituency names.

Source: Fiji Election Office figures, May 1999. 
independents (in relation to registered Fijian voters) in Nadi, Labasa, Yasawa/Nawaka, Nasinu/Rewa, Nausori/Naitasiri, Lautoka City, and most of all in Samabula/Tamavua where Labour fielded one of the most able of its Fijian leaders, Tupeni Baba; in five of these contests the Labour winners were Indians. All seven electorates are in urban or mainly urban areas throughout Fiji. In Samabula/Tamavua and Nausori/Naitasiri, Fijians and Indians made up almost equal proportions of the registered electors, and Generals and Rotumans were 9.6 per cent and 3.2 per cent respectively (Table 4.7).

\begin{tabular}{lrrrrrr}
\hline Table 4.7 Cross-ethnic first preference voting in open electorates \\
& 1 & \multicolumn{1}{c}{ in } & \multicolumn{1}{c}{3} & \multicolumn{1}{c}{4} & \multicolumn{1}{c}{5} & \multicolumn{1}{c}{6} \\
1. Serua-Navosa & 5047 & -4906 & 62.6 & 33.3 & 2.5 & 0.4 \\
2. Lomaivuna-Namosi-Kadavu & 2501 & -2335 & 81.1 & 17.3 & 0.7 & 0.01 \\
3. Cakaudrove West & 3404 & -1853 & 68.4 & 17.3 & 11.5 & 0.3 \\
4. Tailevu South-Lomaiviti & 1456 & -1362 & 65.8 & 33.2 & 0.6 & 0.1 \\
5. Tailevu North Ovalau & 1709 & -1214 & 85.6 & 10.2 & 3.3 & 0.3 \\
6. Bua-Macuata West & 1307 & -999 & 59.3 & 37.6 & 2.0 & 0.1 \\
7. Nadroga & 1143 & -971 & 47.5 & 50.8 & 0.9 & 0.2 \\
8. Lau-Taveuni-Rotuma & 2566 & -942 & 76.9 & 7.2 & 3.6 & 8.4 \\
9. Laucala & 1624 & -668 & 49.3 & 42.7 & 3.6 & 3.3 \\
10. Suva City & -1542 & -547 & 47.4 & 28.9 & 10.3 & 4.2 \\
11. Magodro & 196 & -121 & 25.7 & 73.7 & 0.4 & 0.1 \\
12. Cunningham & 991 & -21 & 58.8 & 32.7 & 5.3 & 1.7 \\
13. Lami & 954 & 88 & 68.2 & 18.6 & 11.4 & 1.5 \\
14. Tavua & -476 & 788 & 42.7 & 54.5 & 1.1 & 1.2 \\
15. Ra & -798 & 870 & 61.7 & 37.3 & 0.4 & 0.1 \\
16. Macuata East & -1517 & 1577 & 19.9 & 79.1 & 0.3 & 0.01 \\
17. Ba & -1611 & 1781 & 15.2 & 83.3 & 0.9 & 0.1 \\
18. Vuda & -1795 & 2060 & 27.9 & 69.7 & 1.3 & 0.5 \\
19. Labasa & -2015 & 2288 & 20.9 & 76.0 & 2.0 & 0.1 \\
20. Nadi & -1657 & 2362 & 37.3 & 56.5 & 3.0 & 0.9 \\
21. Nasinu Rewa & -2279 & 2552 & 44.9 & 52.6 & 1.3 & 0.6 \\
22. Yasawa-Nawaka & -2888 & 2577 & 33.6 & 65.6 & 0.3 & 0.03 \\
23. Nausori-Naitasiri & -2328 & 2773 & 47.2 & 48.6 & 1.9 & 1.3 \\
24. Lautoka City & -2613 & 3591 & 38.7 & 53.0 & 4.6 & 2.0 \\
25. Samabula-Tamavua & -3010 & 4285 & 44.4 & 43.3 & 6.8 & 2.8
\end{tabular}

Notes:

1. Differences between actual and projected votes for Fijian political parties and other Fijian candidates (other than Fijian candidates of the FLP).

2. Differences between actual and projected votes for FLP, NFP, and other Indian candidates (calculations include 4,317 votes given to Indian candidates sponsored by the Fijian parties PANU and VLV).

3. Percentage of registered Fijian electors.

4. Percentage of registered Indian electors.

5. Percentage of registered General electors.

6. Percentage of registered Rotuman electors.

Source: Fiji Election Office figures, May 1999. 
My observations in Suva at the time of the elections encourage me to believe that many of these votes were for Labour. However, it is not possible to determine how much of the Fijian support for 'Indian' parties was for the FLP rather than for the NFP. The chart partly reflects the success of the SVT/NFP/UGP Coalition's efforts to encourage 'cross' ethnic voting for shared candidates in many of the open contests. In some electorates the Coalition favoured an NFP candidate, and in others an SVT candidate, while also having the other party field a 'dummy'. The extent to which voters accepted the NFP/SVT coalition's true candidate regardless of party or ethnicity seems to be indicated by huge differences in the votes received by that contender and the 'dummy' (Table 4.5). These differences occurred in most of the electorates included in Figure 4.7.5 The pattern on the left side of the chart shows the extent to which actual votes for the FLP, NFP, and other Indian candidates fell short of the hypothetical support projected on the basis of the number of registered Indian electors in each constituency, and the corresponding support for Fijian parties in excess of what might be expected from the numbers of registered Fijian voters.

The apparently substantial cross-ethnic voting for the NFP and the SVT is more likely to reflect the success of the coalition strategic sharing of contests rather than voters' identification with an ideology and program transcending the ethnic divide. Although the degree of Labour's success in directly attracting the popular Fijian vote remains unclear, the party has certainly made the most successful attempt to build a direct multiethnic following on the basis of ideology and policy. But alliances of primarily ethnic organisations continue to be the dominant form of political cooperation in Fiji, and these coalitions are likely to continue to be intermittently strained by their internal contradictions.

\section{The election outcome}

With 30 Indian and 7 Fijian members of parliament, Labour was the strongest group in the victorious Peoples' Coalition. Although at Labour's initiative, its leader, Mahendra Chaudhry, became the first Indian Prime Minister of Fiji, he selected a majority of Fijian ministers for his cabinet11 of the 17 portfolios, including four from Labour, three from the FAP, and two each from PANU and the VLV. Several were of chiefly rank.

Fiji's president, Ratu Sir Kamisese Mara, refused a request by the FAP, Labour's principal partner in the Peoples' Coalition, that its high-ranking leader Adi Kuini Bavadra Speed, widow of Dr Bavadra, be appointed prime minister. Having faced the threat of losing his Fijian party allies a day before his swearing in, Chaudhry warmly acknowledged the importance of Mara's influence in persuading the FAP to accept Labour's leadership. Rabuka himself, while reproving Indians for a 'racial bloc' alignment with Labour and warning against actions that might threaten Fijian interests, nonetheless 
urged Fijians to support the new government-not least from his concern to demonstrate in Fiji and abroad his continued commitment to the Constitution he had played a crucial role in achieving.

Many people contacted the SVT headquarters to ask when 'the protest meetings would be held', only to be told they must accept the election result and perhaps had only themselves to blame for it. A protest march in central Suva organised by the NVTLP attracted little support. It is true that some people may have been deterred by the threat of the Police Commissioner, an ex-army Fijian, to make 'mass arrests' (Fiji Times 26 May 1999). However, the NVTLP had proved a generally weak contender in the elections, and the VLV, whose platform had also relied on ethnic appeals, had now been drawn into the new cabinet after sharing its vote preferences with Labour.

Within weeks of his victory, Chaudhry sought to dispel Fijian anxieties 'about my intentions and those of my government' in a speech to a specially convened meeting of the Council of Chiefs. He viewed the occasion as crucial for enhancing the legitimacy of his leadership of the nation, and his address echoed that of the first Indian to speak before the chiefs, Jai Ram Reddy, which had facilitated the constitutional reform (Lal 1998; Norton 1999). Chaudhry respectfully reaffirmed Reddy's 'assurances...that all communities...look to this great venerable institution for leadership and guidance in the good governance and well-being of our nation' (Fiji Times 14 June 1999:22-3). He promised especially to protect and advance indigenous interests and to consult with the chiefs.

Though many Fijians remained troubled by the appointment of an Indian prime minister, commonly exclaiming that 'this is our land, and a Fijian should lead!', the predominant reaction was acceptance in anticipation of action on Labour's ambitious electoral promises such as a minimum wage, tax reforms, and more jobs and job security. Some SVT leaders privately feared that Chaudhry, whose work and rhetoric had long focused on the plight of ordinary people, might now have the means to achieve an increasing popularity with indigenous Fijians. ${ }^{6}$

To some extent the FLP's success undoubtedly did reflect the widening of a popular base of shared inter-ethnic interests at a time of growing anxiety about employment and living conditions. Nonetheless, the party depended more on its ability to continue to lead an unstable alliance of groups with contradictory interests and agendas. Chaudhry had to contend with the ever-present potential for ethnic conflict within his coalition on such highly sensitive matters as land reform where he planned to improve the security of the tenants (mostly Indians), and over rivalries for cabinet and other government posts. Compounding his problems were imperatives of the international economy that were likely to impose obstacles to his attempts to tackle unemployment and poverty. 
Rabuka regained his parliamentary seat, but quickly relinquished it to become full-time chairman of the Council of Chiefs where, still a potent icon of ethnic power, he had an enhanced capacity to encourage Fijians to either oppose or cooperate with Chaudhry's government. He could at times act as focal point of ethnic resistance, at other times as a mediator bridging the ethnic divide and promoting accommodation. In this respect his position might have been very like that which leading chiefs have long taken in the national political arena (Norton 2000; 1999). The crisis of expiring Indian farm leases, aggravated by Fijian resentment over the election outcome and posing a threat to national economic growth, might have proven to be Rabuka's first challenge in this role. During the months following the elections some traditional chiefs (including SVT members of parliament) reacted against the Labour victory by declaring that the leases in their districts would not be renewed: 'Fijians have given up the political control of their native land. They are not prepared to give up anything else. They will now be reluctant to share with others' (Tui Wailevu The Daily Post 23 June 1999). ${ }^{7}$

\section{Postscript}

Chaudhry's national leadership inevitably faced trouble over land, the issue of greatest sensitivity to Fijians. The Labour Party constituency included many Indian farmers anxious for the future of their expiring leases on Fijian clan lands. By demanding the retention of ALTA, the longstanding law that regulates the leasing and tends to advantage the tenants, he antagonised the Council of Chiefs and the Native Land Trust Board which wanted the legislation abolished and more control returned to the owners.

Several of Chaudhry's Fijian political opponents encouraged popular alarm on this and other issues, such as the proposal to establish a land use commission, and to extend to needy Indians a 'special loans' scheme originally introduced for Fijians. Aided by sections of the media, these politicians endeavoured to denigrate the new government's actions and policies as threatening indigenous interests. Chaudhry played into their hands when he ignored suggestions that he placate Fijian fears by consulting more with their authorities. For all his good intentions for the welfare of the ordinary people, he soon seemed to many Fijians to embody their long imagined threatening Indian leader. The antagonism toward him extended even to some of his own backbenchers. The orchestrated build-up of hostility created a supportive atmosphere for the violent seizure of his government by a 'rebel' group who masked their agenda for power and economic opportunity in the old familiar rhetoric of indigenous rights under threat from an Indian grab for political power. 
The crisis has posed again Fiji's central dilemma: how can the indigenous demand for political pre-eminence accommodate the non-indigenous citizens who form nearly half the population and contribute so crucially to Fiji's wellbeing? The problem is compounded by rising Fijian expectations of political power. The principle of indigenous paramountcy has in the past been valued as a reassuring counterweight to non-Fijian economic and demographic strength. Ironically, while this constitutional privilege brought little material gains to most Fijians, it favoured continued Indian access to cheap leases and business opportunities.

At least since 1987, however, Fijians have seen control of the state not simply as a reassurance of security, but as a way to economic benefits (jobs, commercial opportunities, finance). The coups of 1987 and 2000 were influenced by these raised economic stakes of political power. The proposed strengthening of the Fijians' position in the state will not lessen the force of this factor, and the violent usurpations by Rabuka and Speight might well be repeated in future Fijian power struggles. As in 1987, the recent coup sparked Fijian rivalries along traditional and provincial divisions. A renewed exodus of Indians with their capital and professional skills can only aggravate such conflicts by contributing to economic recession.

\section{Notes}

Discussions with Brij Lal, Jone Dakuvula, Dale Keeling and Jonathan Fraenkel have helped me in preparing this chapter. However, any errors in negotiating the slippery psephological terrain are either mine, or those of the Fiji Electoral Office.

1 There were significant regional differences in the popularity of the Fijian parties, although some of this difference reflected an agreement between PANU and FAP not to contest in each other's main areas. The SVT was weakest in Ra in northwestern Viti Levu (13 per cent of communal votes), parts of southeast Viti Levu and in the Lomaiviti islands (18 per cent), and in Bua in Vanua Levu (19 per cent), and strongest in Kadavu (77 per cent), Cakaudrove (72 per cent), Lau (44 per cent), Macuata (43 per cent), and in the Suva city electorate of Tamavua/Laucala (40 per cent). PANU averaged 32 per cent of communal votes in the west Viti Levu Fijian communal contests, but had no candidates any where else. The FAP averaged 26 per cent in southeast Viti Levu, 9 per cent in the west, and 6 per cent in the eastern islands. The VLV averaged 30 per cent in the eastern islands, 14 per cent in southeastern Viti Levu, and 10 per cent in western Viti Levu. The most ethnocentric group, the Nationalist Vanua Tako Lavo Party (NVTLP), averaged 12 per cent in southeastern Viti Levu, 7 per cent in the west, and 4 per cent in the east. The Labour Party polled only 1.7 per cent of all Fijian communal votes, but from 8 per cent to 12 per cent in the four electorates where it fielded candidates, who helped split Fijian votes to the benefit of its allies. The Labour Party's Fijian allies each represented a wide spectrum of interests, from subsistence villagers and commercial farmers to urban wage and salary workers, and business people. 
2 For the origins of the Labour Party see Howard 1991; Lawson 1991; Lal 1992 and Sutherland 1992.

3 Of the 12 winning candidates of designated chiefly rank only 3 were SVT, 6 were FAP, 2 FLP, and 1 VLV. Many more chiefly candidates lost their contests.

4 The vote totals do not include invalid votes. In five of the open contests there were no FLP, NFP, or other Indian candidates, and it is clear that here the support for Fijian parties included many Indian votes. These five electorates are very largely Fijian in composition: numbers 1, 2, 3, 5, and 8 in Figure 4.7 (Serua-Navosa, Lomaivuna-Namosi-Kadavu, Cakaudrove West, Tailevu North-Ovalau, and LauTaveuni-Rotuma).

5 The SVT's success in persuading its followers to support NFP candidates in several open contests is indicated also by the fact that in the seven contests where the SVT fielded 'dummy' candidates the average ratio of votes for the NFP against the FLP was 73 per cent, contrasting with an average NFP/FLP ratio of 46 per cent where the SVT supported its own candidates, and 50 per cent in the Indian communal contests (holding also for the urban Indian communals alone).

6 Many Indians were ambivalent at the prospect of an Indian prime minister, fearing a repetition of the 1987 coups. A Suva businessman remarked to me: 'The Fijians, they are good people... but they are immature politically. They are not ready to accept an Indian as prime minister and might react violently'. He feared that if such a reaction further damaged the economy, this would not much concern Fijians as they could simply return to their old subsistence way of life.

7 Immediately after Chaudhry's appointment as prime minister a PANU leader warned of a possible Fijian backlash against their Indian tenants. He claimed that there had been an understanding in the Peoples' Coalition that a Fijian would be nominated for prime minister (Apisai Tora quoted in Fiji Times 20 May 1999:3). 